\title{
Postprint
}

Lynch, J.; Parcero-Oubiña, C. and Fábrega-Álvarez, P. 2020: “A field experience of documentation and analysis through 3D mapping and surface survey in the Hualfín Valley (Catamarca, Argentina)". Digital Applications in Archaeology and Cultural Heritage 17: e00145.

\section{A field experience of documentation and analysis through 3D mapping and surface survey in the Hualfín Valley (Catamarca, Argentina)}

\author{
Julieta Lynch *, César Parcero-Oubiña **, Pastor Fábrega-Álvarez ***
}

* División Arqueología, Museo de La Plata. CONICET, FCNyM, UNLP, Paseo del Bosque s/n, La Plata, Argentina. julietalynch@yahoo.es

** Instituto de Ciencias del Patrimonio (Incipit), Consejo Superior de Investigaciones Científicas (CSIC), Avenida de Vigo, s/n 15705 Santiago de Compostela, Spain. ORCID Id: 0000-0003-3000-4232

*** Instituto de Ciencias del Patrimonio (Incipit), Consejo Superior de Investigaciones Científicas (CSIC), Avenida de Vigo, s/n 15705 Santiago de Compostela, Spain. ORCID Id: 0000-0001-5371-438X

\section{Abstract}

This paper presents an experience developed in the Hualfín Valley (Catamarca, Argentina), aimed at testing the utility and suitability of non-invasive methods for documenting and analyzing sites of inconspicuous nature. The documentation of architectural remains and of archaeological materials with reference to them has been common fieldwork practice in this region. However, this produces a partial documentation of the sites and poses important problems to characterize sites without obvious visible architectural remains. Through a combination of remote sensing (satellite imagery, terrestrial and UAV-based photogrammetry) GIS analysis and field survey, two sites in the area were documented in detail with a cost- 
effective procedure that has allowed us to produce a more refined interpretation of them and their archaeological contexts. Considering the simplicity of the methods and the tools involved, we suggest that this methodology can inspire future work in this and similar regions.

\section{Keywords}

Archaeological prospection; Field survey; 3D documentation; Photogrammetry; GIS; Preservation through documentation; NW Argentina

\section{Introduction}

In the last years, the generalization of different digital technologies has allowed a significant leap forward in the common methods and tools in field archaeology. Some of these technologies, or even most of them, have been around for decades now and are actually not new anymore (such as GIS, satellite imagery or photogrammetry). However, they have become really accessible both in terms of cost and user-friendliness. Although they still require some specialized skills and one needs to be well aware of their conceptual and technical foundations, they are now much more accessible than just one decade ago. On the other hand, most of these technologies are nowadays cost-accessible for the average archaeological project. Depending on our needs, a combined use of open source and free software, freely-accessible digital data and a few consumer-grade tools (a digital camera, a laptop, a GPS navigator or an entry-level drone) will allow us to cover a large suite of documentation and analysis procedures. Besides that, it has been suggested that the impact of these "technological leap" might go well beyond allowing a faster, easier and more detailed documentation; it has the potential to "allow us to decouple measurement from interpretation, data from information, leading to a fundamental alteration of the abstractive process in archaeology" (Opitz and Limp, 2015: 359).

A quick review of the existing bibliography would show us how the spreading of these tools and methods is still very uneven across regions and research periods. In particular, their use in Latin American archaeology is much less frequent than in other parts of the world. In this paper we will present a case-study where the combined use of some affordable and readily available tools and methods has produced a detailed documentation and characterization of some archaeological sites whose intrinsic characteristics made them unsuited for more traditional field documentation methods. The work is part of a research project aimed at characterizing 
archaeologically the valley of Hualfin, a sector of the province of Catamarca (NW Argentina) that, to a great extent, is a good example of the characteristics and challenges of fieldwork and research in this area. This is a sector where previous archaeological surveys were fragmentary, mainly directed at specific settlements (Lynch, 2013; Lynch et al., 2013). Fieldwork here involves some practical challenges, mostly related with a rugged topography and a poor superficial visibility of the archaeological sites. Leaving the most monumental sites aside, in the recent years some new sites have begun to be discovered. They are characterized by an inconspicuous nature, with few remains of buildings visible on the ground. That characteristic, together with an explicit interest in the analysis of the historical processes from a landscape perspective, demands a reassessment of the field methodologies used in the area so far, based mainly on the documentation of the remains of buildings and archaeological materials within them at the scale of single sites.

Against this background, our objective in this paper is to present a methodology for the documentation and characterization of this kind of sites based on the use of simple tools and on a combination of field and aerial observation. Two sites with different characteristics will be used as case studies to illustrate the benefits and drawbacks of this methodology, aimed at tackling some of problems and challenges inherent in the archaeology of this region.

\section{Case-study area and sites}

The Hualfín valley is part of the geological region Sierras Pampeanas Occidentales, composed of Lower Paleozoic metamorphic and plutonic bedrock under Cenozoic sedimentary rocks mainly of volcanic origin (Seggiaro et al., 2014). The Hualfín river is a major geomorphological agent that cuts across several Quaternary alluvial terraces. Most of the archaeological sites known in this area are located on or around those terraces. While some of them have been investigated more or less intensively (Balesta et al., 2011; Lynch, 2013; Lynch et al., 2013; Wynveldt et al., 2013), large-scale excavations have been uncommon to date. On the other hand, most archaeological research has relied on the documentation of the remains of buildings that are still visible on the ground surface, and the collection of material elements (pottery, lithics) found within those buildings. When such collections have been done, buildings have always been used as the spatial reference for the findings; consequently, surveys have been oriented to those areas with visibly preserved built remains (Figure 1). 


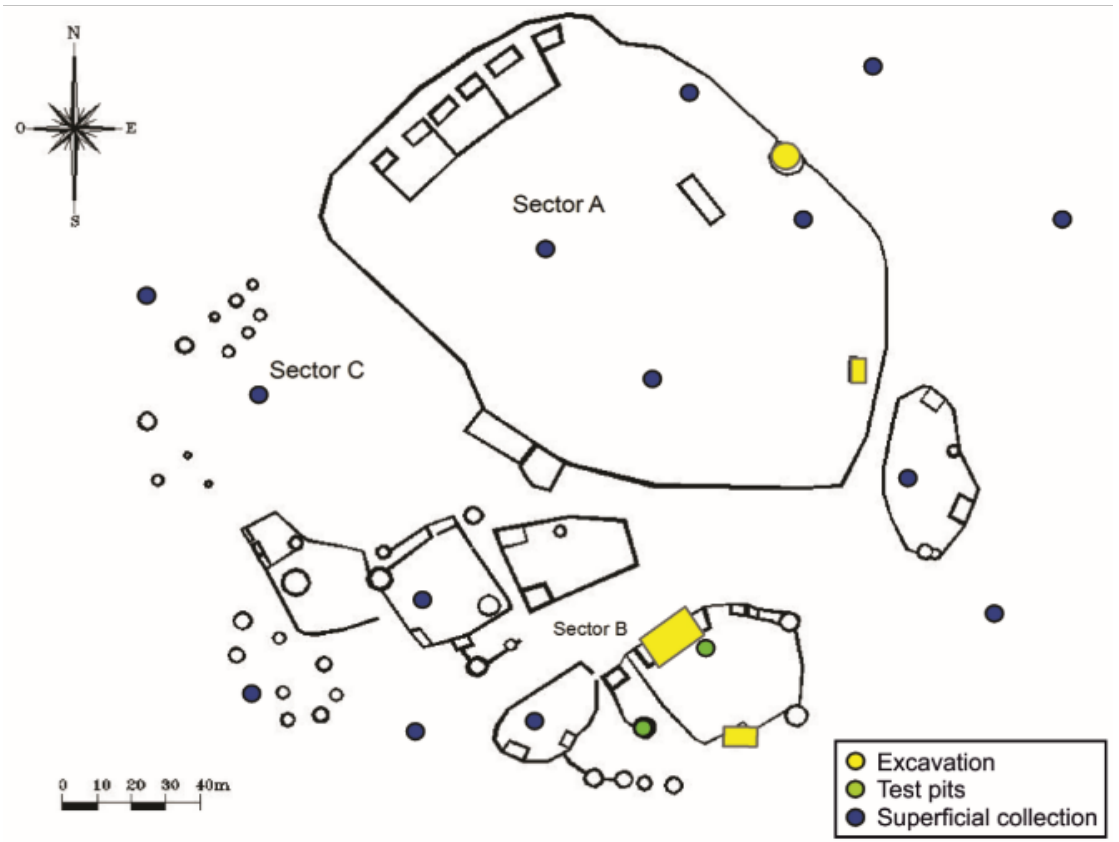

Figure 1. The documentation of the site Hualfín Inka by one of the authors is a good example of the traditional procedures used in the area (Lynch, 2013)

Nevertheless, other sites lacking a visible architecture have begun to be documented recently, thanks to the adoption of a landscape-based perspective for the understanding of the prehispanic settlement in the area. In this paper we will focus on two of those sites with subtler archaeological remains: Villavil 1 and Villavil 2 (Figure 2). The problems and challenges involved in their documentation might constitute a good example and paradigm of many other similar archaeological sites in the region. 


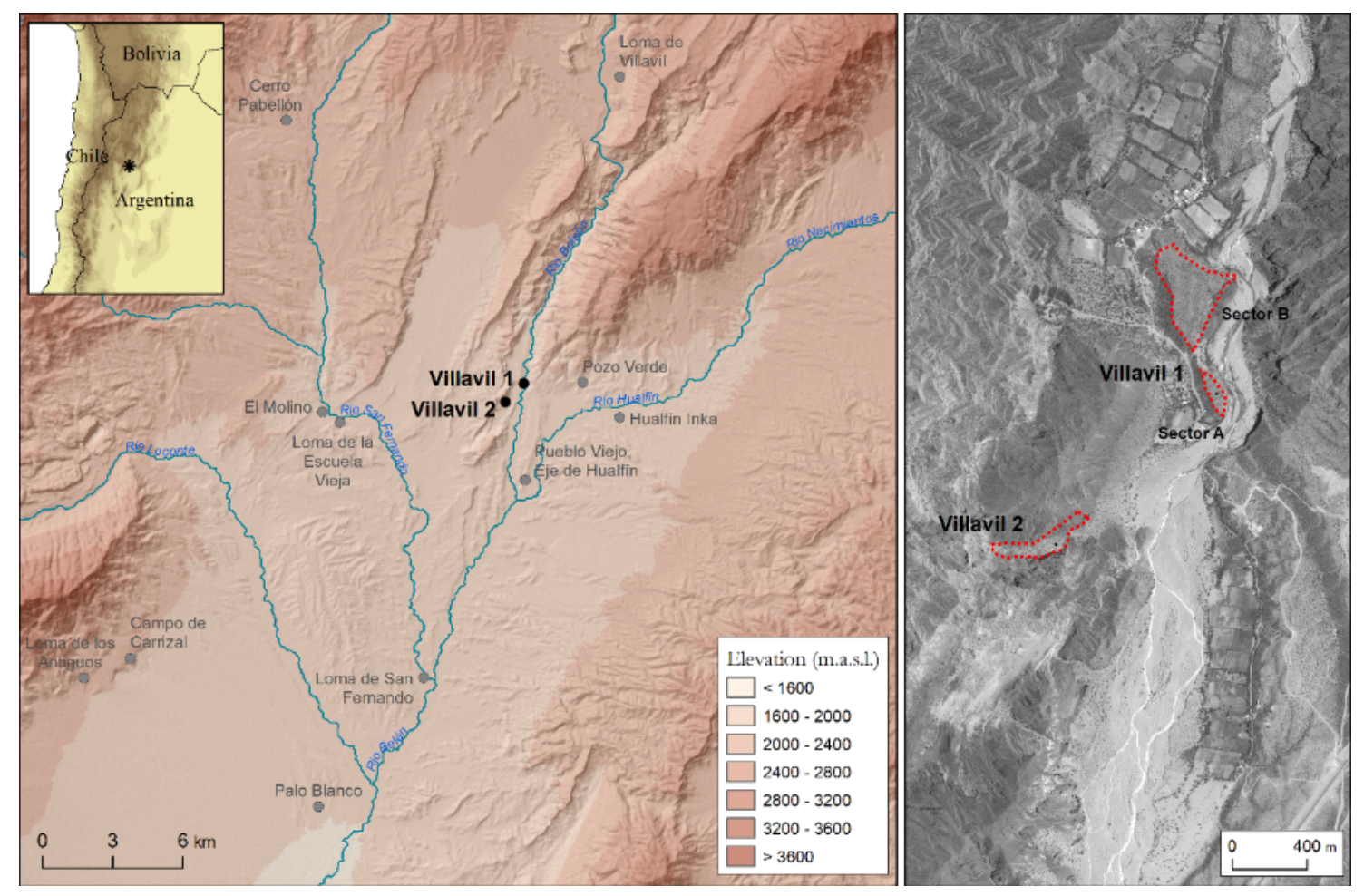

Figure 2. Location of the Hualfín valley. The sites of Villavil 1 and 2 within their immediate context, showing other prehispanic sites known in the area (left). Location of the sites in the lower Bolsón river valley, on top of a panchromatic WorldView 2 image (right)

\subsection{Villavil 1}

Villavil 1 is located on an alluvial terrace of the Bolsón-Villavil river, only $5 \mathrm{~km} \mathrm{~W}$ from the main Inka site in this area, Hualfín Inka (Lynch, 2013), although in a separate valley with no visual connection. The site occupies two contiguous elevated plateaus next to the river course. It was first documented in 2008, when both plateaus were named sector A and B respectively (Figure 2) (Lynch, 2014). In both of them very subtle remains of dispersed rectangular and circular buildings, as well as linear walls, were identified. Local rocks taken from the immediate proximity were used in their construction, using either single our double-lined walls. Their preserved height ranges just between $20-30 \mathrm{~cm}$. at best, which implies a low visibility on the ground. The extension and density of these remains were difficult to establish with some confidence. 


$\begin{array}{clcc}\text { Sample Id } & \text { Lab } & \begin{array}{c}\text { Uncalibrated } \\ \text { date (years BP) }\end{array} & \begin{array}{c}\text { Calibrated dates, 2 } \sigma \\ \text { (OxCal, ShCal 13 ) }\end{array} \\ \text { LP-2998 } & \text { Latyr } & 850 \pm 60 & \text { AD 1046-1369 } \\ \text { LP-2976 } & \text { Latyr } & 1220 \pm 60 & \text { AD 685-762 } \\ \text { LP-3003 } & \text { Latyr } & 1380 \pm 80 & \text { AD 573-887 } \\ \text { LP-2979 } & \text { Latyr } & 2190 \pm 80 & 391 \text { BC - AD 16 }\end{array}$

Table 1. Radiocarbon dates for the site Villavil 1

Pottery collected on the surface at the moment of the first discovery suggested a variety of types and periods, and the site as a whole was interpreted as having two main phases of use: first during the Early/Middle Period (ca. 250 BC- AD 1000) (Ciénaga and Aguada style) and later during the Late (Desarrollos Regionales) and Inka periods (ca. AD 1000 / 1430) (Lynch, 2014). Samples taken from a test pit excavation allowed to obtain four radiocarbon dates whose high deviation makes them only relatively useful for the most recent periods. Even so, the results (Table 1) reinforce the impression of a long occupation, but with no further clues on the extent and intensity of the occupation through time. Besides that, the surface pottery collection and the test pit excavations were limited to a small sector of the site, which left uncertainty as to what extent these results were applicable to the site as a whole.

\subsection{Villavil 2}

Villavil 2 was first discovered in 2015. It occupies an uncommon topographic location on top of a vertical cliff with very difficult access that ends in a dead-end gorge where different remains of ancient activity are visible on the ground. The scenic location, on a prominent and dominant position with a large visibility over the surrounding area, is one of the most remarkable characteristics of the site. Besides prominent, the location is also hardly accessible, since the only way to reach the site is by literally climbing a nearly vertical rocky wall.

The point of access to the site is occupied by a narrow promontory where some large rocky outcrops have been engraved with different rock art motifs (Figure 3). Actually the presence of rock art is the second most significant characteristic of this site, since rock art had not been registered in this area beforehand. Some reddish-colored sandstone blocks are covered with a black layer on the surfaces where the motifs were engraved. The iconography was preliminarily 
associated to the late pre-Inka or Inka Periods, although modern motifs are also visible (Lynch, 2015; Lynch and Lynch, 2018).

A remarkable characteristic of these rock art outcrops is their fragility. Different natural processes have impacted the preservation of most of these rocks, being two especially noticeable:

1. Weathering (exfoliation) of the superficial layers, where the rock art was engraved. This is clearly visible in most of the rocks, and it seems reasonable to guess that it has caused the loss of part of the original motifs (see for instance the rocks in Figure 3).

2. Rockfalls that have affected at least some areas, as for instance the large rock shown in Figure 4: the rock is clearly broken after falling from its original position, and the face that is engraved (shown with an arrow) is now literally hanging over the cliff.

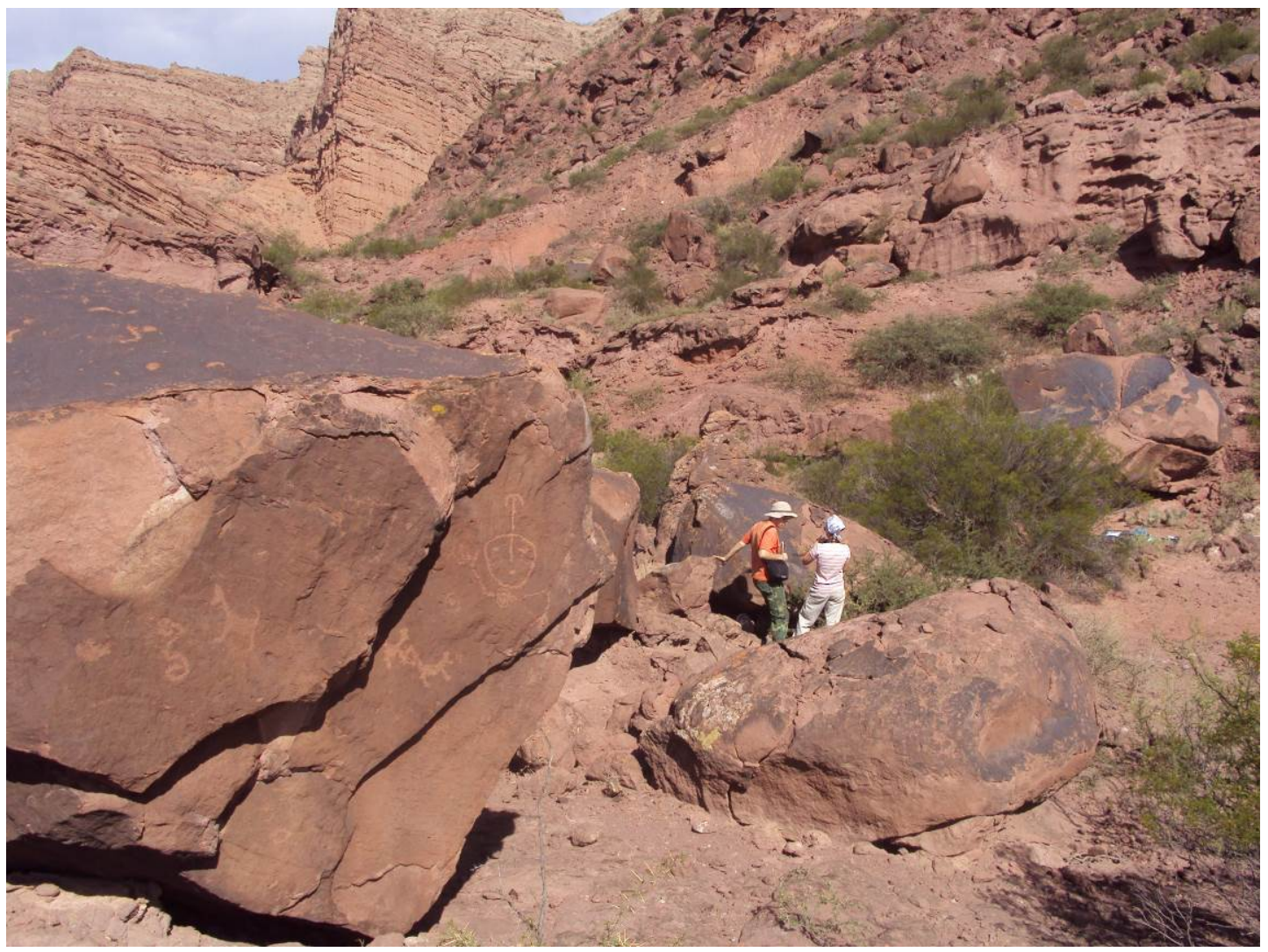

Figure 3. General view of the rock art area in Villavil 2 


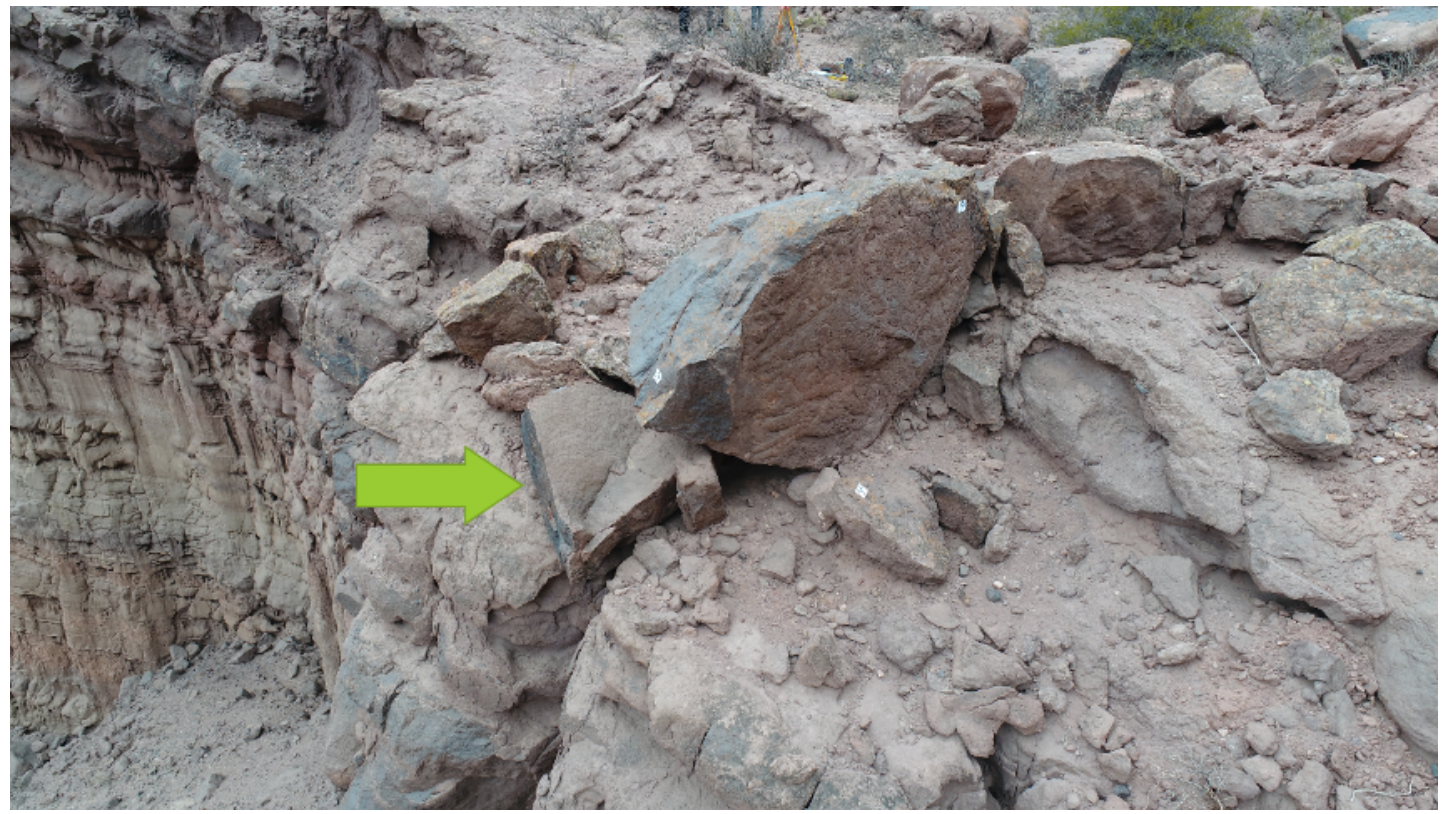

Figure 4. This broken rock has now an engraving hanging over the cliff

Behind this narrow promontory with rock art, a dead-end gorge is reached, where the subtle remains of some constructions are visible. These buildings are difficult to see on the ground because of their poor preservation. Abundant fragments of pottery and lithic material are also easily visible on the ground; after a first general review, they have been assigned to late local and Inka styles (Lynch, 2015).

\section{Materials and methods}

The construction of a detailed record of both sites became a primary need in order to characterize them, but also posed some practical challenges.

- The sites are composed of a multiplicity of archaeological elements: subtle remains of built areas, surface scatters of pottery and lithic objects, rock art panels.

- Topography is not only a key element to understand the distribution of those different elements across the sites, but also a key component itself of the sites, especially in Villavil 2, meaning that it should be documented too. 
- Some elements (especially some rock art panels) are extremely fragile, making their documentation important beyond the needs of our project, as a way of keeping accurate record of something that might disappear, or radically change, in the near future.

- Both sites are located more than 1,000 km far from our base institution (La Plata), which means that we needed to document as much information as possible in one single fieldwork season, since the chances of revisiting the sites in the short term are low.

- We had limited means available: 10 days and a team of 5 people.

The characteristics of both sites made them unsuited for an archaeological approach based on the use of the remains of buildings as the main framework of reference for documenting and analyzing their nature and functionality, as was common here. Surface collection seemed an essential part for assessing the chronology and function of the sites, but the architectural elements are tenuous, poorly preserved and often hardly visible on the ground, implying that a large part of the archaeological materials visible on the ground cannot be associated with any specific built feature.

Drawing from previous experiences in similar, nearby regions, we decided to take advantage of a particular characteristic of the area, the sparse vegetation cover, to build our approach upon a perspective from above (Parcero-Oubiña et al., 2017; Parcero-Oubiña et al., 2016). However, in this case some adjustments were needed, mainly because we are dealing here with a larger variety of elements that demand a documentation of different granularity: from the broader scale of the site topography to the high detail of the rock art motifs located in vertical panels not visible from above. In the next sections we will describe the methodology followed for the geometric documentation of the sites within their topographic settings and for the surface collection of materials on the ground. Taken together, they produced a very detailed documentation of the two sites, which allowed us to infer some functional and chronological aspects about them.

\subsection{UAV-based documentation}

To produce a detailed documentation of both sites and their topographic settings, we initially relied in a combination of low altitude aerial images, taken from a UAV, and photogrammetry and computer vision techniques (structure from motion), an approach that is becoming common practice in archaeology (Campana, 2017). Our UAV of choice was a DJI Phantom 4, part of a 
line of consumer-grade drones that, equipped with different cameras and sensors, has become very popular for archaeological applications in the last years (Hanus, 2018; Thomas, 2018; Wernke et al., 2017). The DJI Phantom is both easy to operate and reliable; depending on flight altitude and the characteristics of the camera used, it is capable to capture highly detailed conventional digital images with ground resolutions of down to $1 \mathrm{~cm}$ (Field et al., 2017). The images were later processed in Agisoft PhotoScan 1.4 in order to produce both orthoimages and 3D models of the two sites. PhotoScan is a software that is based on "digital photogrammetry

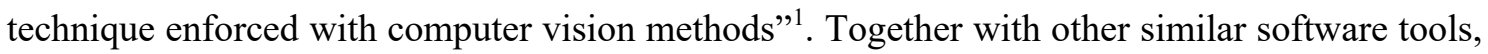
PhotoScan has become extremely popular in archaeology in the last years as an affordable and user friendly, yet powerful, tool to produce a detailed 3D documentation of a vast range of archaeological elements: objects, excavation units, sites and even landscapes (De Reu et al., 2014; De Reu et al., 2012; Doneus et al., 2011; Opitz and Cowley, 2013; Remondino, 2011; Verhoeven, 2011; Verhoeven et al., 2012).

\begin{tabular}{|c|c|c|c|c|c|c|c|c|c|c|c|}
\hline & \multirow[b]{2}{*}{$\begin{array}{l}\text { Mapped } \\
\text { area }(\mathrm{Ha})\end{array}$} & \multirow[b]{2}{*}{$\begin{array}{l}\text { Total } \\
\text { photos }\end{array}$} & \multirow[b]{2}{*}{$\begin{array}{l}\text { Mean flight } \\
\text { altitude (m) }\end{array}$} & \multicolumn{2}{|c|}{ Number of points } & \multicolumn{2}{|c|}{$\begin{array}{l}\text { Output } \\
\text { resolution }(\mathrm{cm})\end{array}$} & \multicolumn{2}{|c|}{ Georref. } & \multicolumn{2}{|c|}{$\begin{array}{l}\text { Time needed } \\
\text { (hours) }\end{array}$} \\
\hline & & & & $\begin{array}{l}\text { Sparse } \\
\text { cloud }\end{array}$ & $\begin{array}{l}\text { Dense } \\
\text { cloud }\end{array}$ & Ortho & DSM & GCP & $\begin{array}{l}\text { RMSE } \\
(\mathrm{cm})\end{array}$ & $\begin{array}{l}\text { Field } \\
\text { capture }\end{array}$ & $\begin{array}{l}\text { Proce } \\
\text { ssing }\end{array}$ \\
\hline Villavil 1 & 39.9 & 273 & 73.0 & $437 \mathrm{k}$ & $61,021 \mathrm{k}$ & 2 & 8 & 13 & 1 & 1.5 & 7 \\
\hline Villavil 2 & 18.0 & 1,388 & 50.5 & $348 k$ & $92,542 \mathrm{k}$ & 1.5 & 6 & 22 & 9 & 4 & 30.5 \\
\hline
\end{tabular}

Table 2. Summary of the results of the construction of the 3D model

Table 2 shows a summary of the input data and results obtained for both sites. The parameters chosen for the $3 \mathrm{D}$ reconstruction were:

- Photo Alignment accuracy - Medium ${ }^{2}$

- Dense Point Cloud creation - Medium, Moderate depth filtering

The density of images is remarkably higher in Villavil 2 for one main reason: the complex topography of the site and the abundance of large outcrops created numerous hidden areas and dead spots that made necessary the acquisition of a large number of images to guarantee a full

\footnotetext{
${ }^{1}$ As described in www.agisoft.com. PhotoScan was renamed Agisoft Metashape after version 1.5.

${ }^{2}$ High accuracy is always the preferred choice here. In this case, we unwittingly used medium accuracy; we only realized that after having finished all the processing stages. Since the results were good enough for our purpose, we decided to accept them instead of redoing all the processing.
} 
coverage with enough overlap. The topographic setting of Villavil 1 is much gentler and one single flight was enough to cover it completely. In any case, the time needed in both cases to take the photos in the field can be considered minor, especially compared with the accuracy and utility of the results.

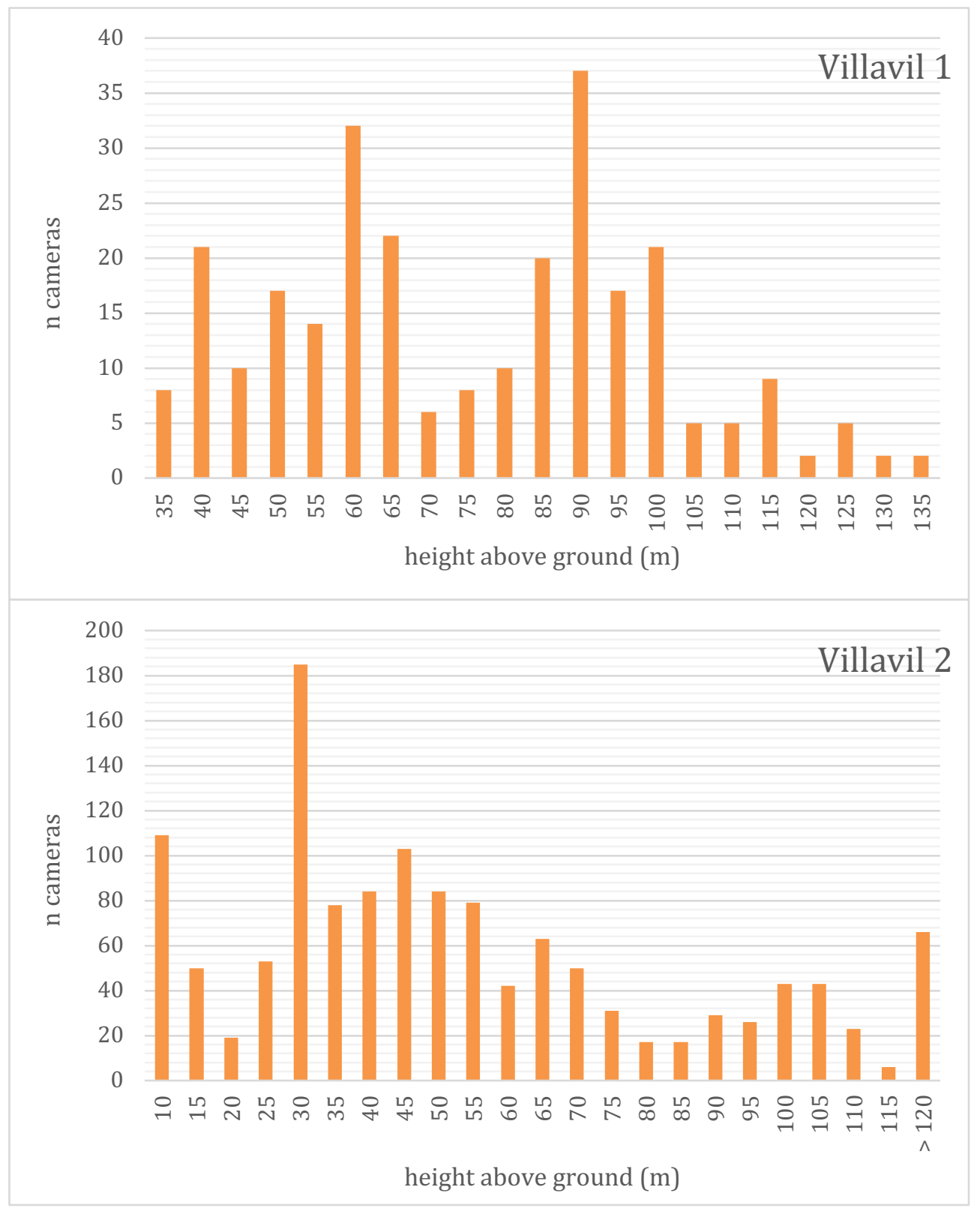

Figure 5. Histograms of altitude above ground of the photos used to produce the models of Villavil 1 (top) and Villavil 2 (bottom)

In effect, the final results constitute a very detailed documentation of both sites within their topographic settings. The model of Villavil 1, composed of a DSM of $8 \mathrm{~cm}$ and an orthoimage 
of $2 \mathrm{~cm}$ resolution, provides detail enough to clearly identify the subtle remains of many stone walls that are barely visible on the ground. The average altitude above ground of the aerial photos was $73 \mathrm{~m}$, with most of them taken at around $60 \mathrm{~m}$ or $90 \mathrm{~m}$, depending on the sector (Figure 5, top). A photointerpretation of this 3D model and the orthoimage has allowed us to improve significantly the existing sketch of the site, creating a map that is both accurate and highly detailed (Figure 6). With 13 Ground Control Points measured with total station, the georreferencing accuracy of the model is $1.1 \mathrm{~cm}$ (RMSE).

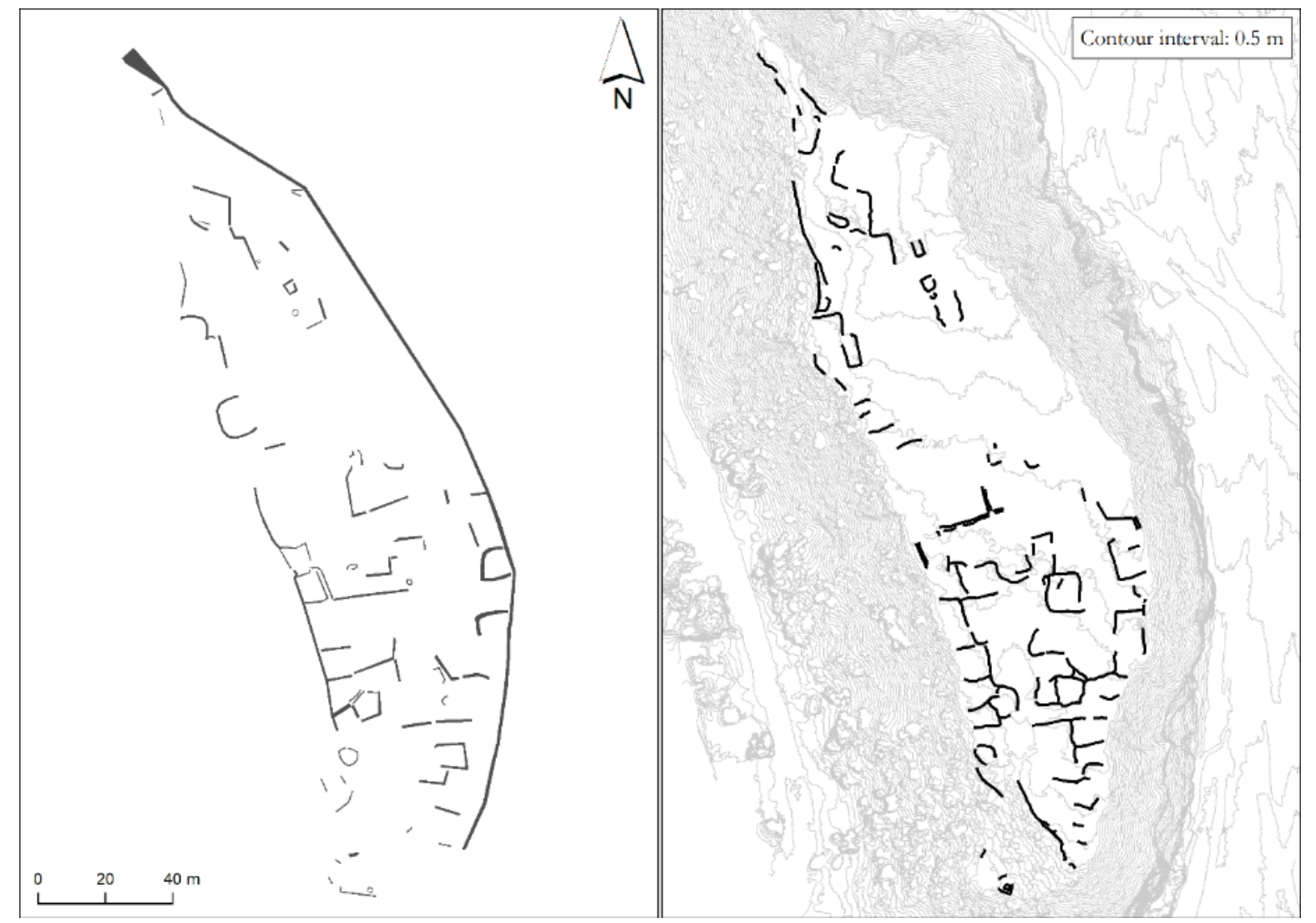

Figure 6. The new archaeological map of Villavil 1, sector A (right) improves significantly the existing sketch (left), not only by including the topography but also by refining the shape and location of the remains of built structures

In Villavil 2 the difficult topographic conditions pose a major challenge for documentation using any traditional, ground-based methods. On the one hand, and as happens in Villavil 1, the archaeological evidence is scattered across a large area, and consists of a varied assortment of elements: subtle remains of walls and enclosures, rock art and fragments of pottery and stone objects and debris. On the other hand, topography is itself an important element of the site, 
something that needs to be well documented along with features and materials, within one single and uniform dataset. In order to fulfill these conditions, a larger number of photos had to be taken, combining different flight altitudes in order to obtain a documentation of multiple granularity, from the site as a portion of the landscape to the rock art motifs in high detail.

The final model consists of a DSM of $6 \mathrm{~cm}$ and an orthoimage of $1.5 \mathrm{~cm}$ resolution where, again, the subtle remains of small circular and quadrangular enclosures are well visible. Besides that, and maybe more importantly in this particular case, the scenic topographic setting of the site is well captured in this model, which becomes extremely useful to describe and analyze it (Figure 7). With 22 Ground Control Points measured with total station, the georreferencing accuracy of the model is $9.2 \mathrm{~cm}$ (RMSE).

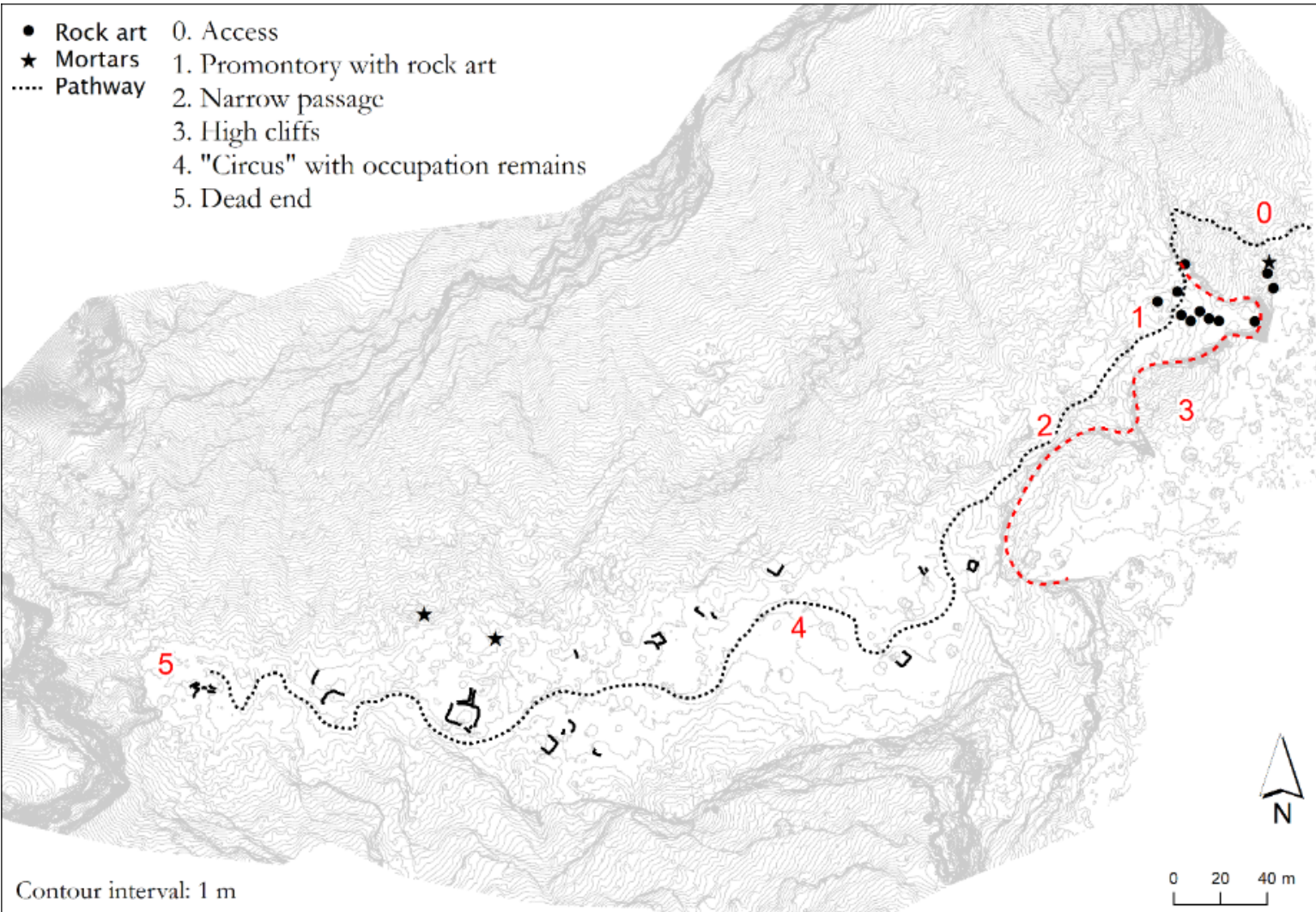

Figure 7. Archaeological map of Villavil 2 


\subsection{Photogrammetric documentation of the rock art panels}

The use of low altitude aerial images allowed us to produce a very detailed geometric documentation of both sites. But there still remained some areas where either yet more detail, or a different form of documentation, was necessary. The rock art panels are the main elements for which a complementary documentation was needed, since the aerial approach lacked detail enough to record them. Besides detail, most of the rock art motifs are engraved on the vertical faces of rock outcrops, something that renders vertical aerial images insufficient.

As happens with any other remains in these sites, location was for us a major component in the documentation of the rock art, in three complementary scales:

- The location of the rocks in the site

- The location of the panels in the rocks

- The location of the motifs in the panels

As we have already shown, rock art is especially fragile in this site, and it is here where our purpose of documentation as a mode of virtual endurance becomes more evident. Besides the immediate needs of our current research, we felt that the creation of an accurate and usable archive of the rock art panels in Villavil 2, as faithful as possible, might be the only way to guarantee its preservation in the long term.

The methodology we adopted used two complementary zooms:

- Firstly, we produced a more detailed UAV-based model for the area with rock art, by taking an extra round of aerial images of that area at a lower altitude.

- Secondly, we produced detailed models of each individual outcrop from close distance photos taken on the ground with an average digital camera (Canon EOS REBEL T3i). Occasionally this was complemented with close distance aerial images for occluded parts, such as the panel shown in Figure 4 or the top of some of the highest outcrops.

There are a total of 9 rocks with rock art motifs in the promontory located at the entrance of the site, plus other two located downslope, at the bottom of the promontory (Figure 7). Although somehow different in size and volumetric complexity, all but one are large boulders with the rock art motifs engraved on their vertical sides. The only exception is a panel located on a flat rock at the very edge of the promontory (number 7 in Table 3 ). 


\begin{tabular}{|c|c|c|c|c|}
\hline Rock n. & $\begin{array}{l}\text { Approximate } \\
\text { volume }\left(\mathrm{m}^{3}\right)\end{array}$ & $\begin{array}{l}\text { Total } \\
\text { photos }\end{array}$ & $\begin{array}{l}\text { Mesh: } \\
\text { faces }\end{array}$ & $\begin{array}{l}\text { RMSE } \\
\text { (cm) }\end{array}$ \\
\hline 1 & 23.4 & 197 & $1,268 \mathrm{k}$ & 0.8 \\
\hline 2 & 7.2 & 81 & $743 \mathrm{k}$ & 1.2 \\
\hline 3 & 20.2 & 110 & $822 k$ & 2.8 \\
\hline 4 & 8.0 & 147 & $489 \mathrm{k}$ & 0.3 \\
\hline 5 & 3.2 & 109 & $546 \mathrm{k}$ & 0.7 \\
\hline 6 & 3.5 & 145 & $1,008 \mathrm{k}$ & 0.8 \\
\hline $7^{*}$ & 0.3 & 34 & $441 \mathrm{k}$ & 0.2 \\
\hline 8 & 5.6 & 128 & $560 \mathrm{k}$ & 0.8 \\
\hline 9 & 9.9 & 196 & $561 \mathrm{k}$ & 1.8 \\
\hline 10 & 10.6 & 128 & $931 \mathrm{k}$ & 1.4 \\
\hline 11 & 17.7 & 101 & $735 \mathrm{k}$ & 3.1 \\
\hline Average & 10.0 & 125 & $737 \mathrm{k}$ & 1.3 \\
\hline
\end{tabular}

Table 3. Summary of the results of the construction of the 3D models of the rocks with rock art

An individual model was built for every single rock, resulting in the production of 11 separate models $^{3}$. The targets used in their construction were georeferenced using the same coordinate system as the one used for scaling and georreferencing the UAV-based model. Table 3 shows a summary of the input data and results obtained for all the rocks, including the average error (RSME) calculated with respect to the actual coordinates of the targets (between 3-10 targets per model). The parameters chosen for the $3 \mathrm{D}$ reconstruction were:

- Photo Alignment accuracy - Medium ${ }^{4}$

- Dense Point Cloud creation - Medium, Moderate depth filtering

\footnotetext{
${ }^{3}$ A streamlined version of these models is accessible at https://sketchfab.com/sesary

${ }^{4}$ See footnote 1 .
} 
The differences in the size of the models (point clouds, mesh) correspond essentially with the different size (volume) of the rocks. This means that the degree of detail obtained is equivalent in all cases. As was intended, this detail is much higher than the detail of the general, topography-oriented UAV-model, and allows to accurately represent not only the detailed shape of each rock, but also the detailed location, form and texture of each rock art motif.

Since all these individual models are georeferenced in the same system as the UAV-based model (WGS 84 UTM zone 19S), they can be blended together to produce a general model of the whole site with a different granularity, showing an extremely high detail in the rock art surfaces, and a coarser (although still very detailed) resolution in the rest of the site ${ }^{5}$. Although at the moment it is still difficult to manage and use as a whole due to its large size (ca $3.2 \mathrm{~Gb}$ in Cloud Compare .bin format), it constitutes a powerful dataset open to multiple uses and virtual manipulation in the future.

\subsection{Surface survey collection}

Surface collection has been for a long time a standard method in archaeology for characterizing human activity both within sites and at a landscape scale, especially in contexts with a good visibility of archaeological materials on the ground (Banning, 2002). As was said, that is a general characteristic of both Villavil 1 and Villavil 2, although some differences exist. Vegetation is in general thin, mainly consisting of scattered bushes, with a large portion of sandy bare earth. While the latter make excellent places for the visibility of artifacts, the former are usually rather opaque. Terrain slope is also irregular, from large flat areas (especially in Villavil 1) to portions with steeper banks where runoff has caused some deep erosion events and the displacement of smaller artifacts from their original position.

In order to control the effect of those differences on the results of our surface collection, a sampling strategy was designed where the visibility and stability of terrain were taken into consideration. Since a full coverage survey was far beyond our reach, we designed a methodology aimed at guaranteeing a homogeneous coverage of both sites within our limited fieldwork time, while minimizing the effects of surface visibility and stability. The strategy

\footnotetext{
${ }^{5}$ For illustration purposes, we have produced a short video that provides a quick glimpse of the model. It can be accessed at https:/www.youtube.com/watch?v=1H77SNdwgWU\&t $=6 \mathrm{~s}$
} 
consisted of two complementary steps. First, a regular grid of $25 \mathrm{~m}$ x $25 \mathrm{~m}$ square survey units was designed to cover the whole area of both sites (Figure 8).

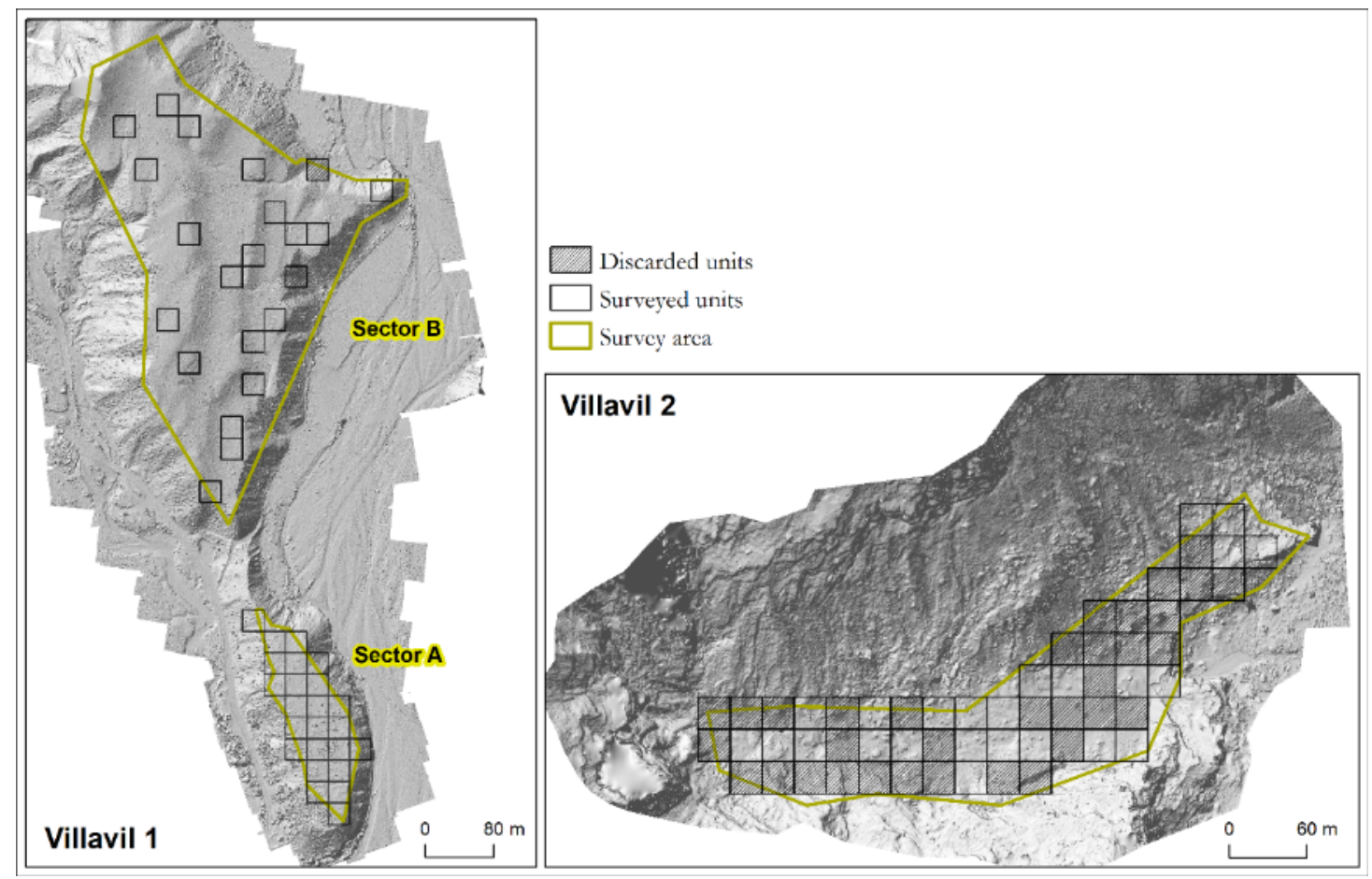

Figure 8. Survey area, grid and sectors

Second, inside each $25 \mathrm{~m} \times 25 \mathrm{~m}$ square unit a circular collection sector of $3 \mathrm{~m}$ radius was placed. Instead of pre-determining the specific location of these sectors within the square grid, the fieldwork surveyors were free to locate them in any area inside the square unit with optimal conditions of both visibility and terrain stability. The exact location of the central point of each circular collection sector was accurately mapped with a DGPS. All the archaeological objects found within these sectors were collected.

This system combines both a systematic basis, since all the area is surveyed following a regular and homogeneous pattern, with an "informed-random" approach, where only a portion with good conditions of the survey units is actually collected. This minimizes the effects of taphonomic and observational factors on the comparison of the density and variety of elements collected across the site.

In theory, this system would have implied the actual collection of materials in $4.48 \%$ of the total area of both sites (a circular sector of $28 \mathrm{~m}^{2}$ per $625 \mathrm{~m}^{2}$ square unit). However, the total surface 
that was finally surveyed is a bit smaller, for two possible reasons. First, some grid units had to be left out of the collection strategy for lacking any areas with good preservation and/or visibility. This was especially frequent in Villavil 2, where a large part of the survey area consists of rocky surfaces with little or no soil.

A second reason for discarding some survey units happens in Sector B of Villavil 1, an area where a preliminary overview indicated the existence of a very low density of architectural remains. This was later confirmed by the results of the UAV documentation. In this case, rather than characterizing the intensity and chronology of the site, the aim was actually to verify the existence of evidence enough to support the extension of the site across this sector. Due to that, in that large sector we decided to randomly select only 1 out every 7 grid units (Figure 8). In the end, the sum of areas where materials were fully collected is $1.922 \mathrm{~m}^{2}$; the ratio of surveyed/total/"useful" surface per site is summarized in Table 4.

\begin{tabular}{cccc} 
& $\begin{array}{c}\text { Villavil 1, } \\
\text { sector A }\end{array}$ & $\begin{array}{c}\text { Villavil 1, } \\
\text { sector B }\end{array}$ & Villavil 2 \\
\hline Total area (Ha) & 12.4 & 96.5 & 37.2 \\
"Useful" area (exc. discarded units) & 12.4 & $\mathrm{n} / \mathrm{a}$ & 15.9 \\
Collection area $\left(\mathrm{m}^{2}\right)$ & 678.6 & 565.5 & 678.6 \\
\% of total area & 5.4 & 0.5 & 1.8 \\
\% of "useful" area & 5.4 & $\mathrm{n} / \mathrm{a}$ & 4.2
\end{tabular}

Table 4. Percentage of area actually surveyed in each site/sector

\section{Results and discussion}

In the next sections we will describe the main results of the survey in both sites. Since the main results of the UAV-based documentation have already been shown, here we will focus on the analysis of the results of the field survey and on what they tell us about the nature, function and chronology of both sites. 


\subsection{Villavil 1}

Perhaps the most noticeable result of the superficial collection in Villavil 1 is the very uneven density of objects collected in sectors A and B, which is obvious at first sight (Figure 9). The difference is especially noticeable in the density of surface pottery. This seems to reinforce what our first impression suggested, based on the low density of visible features in sector B: properly speaking, the settlement area in Villavil 1 is limited to sector A. The existence of some scattered fragments of pottery and, especially, of lithic debris might suggest that sector B was used as an area of relatively frequent but non-permanent activity. Actually, the immediate utility of any of those two sectors is very limited, besides their suitability for settlement. They are areas of shallow sandy soil, with limited potential for cultivation, hard if not impossible to irrigate (they are located $30 \mathrm{~m}-40 \mathrm{~m}$ above the level of the surrounding rivers) and also with limited utility as pastureland.

The picture becomes more informative if we focus on the different types of pottery collected in sector A. Besides the large number of undetermined elements, the most noticeable thing is the abundance of pottery sherds belonging to the Early/Middle period (Ciénaga/Aguada style, ca. AD 100-1000) (Figure 9). Although in the first approach to the site a long chronological sequence was proposed (Lynch, 2014), the results of this more systematic survey strongly suggest that there is a period of much more intense occupation in the site between AD 1001000 , and evidence only of minor activity before and after that time. This is especially relevant for our project, whose main objective is the analysis of the dynamics of the later periods in the region. In that respect, it is worth noting that the documentation of pottery styles from the Late Intermediate (Desarrollos Regionales) and Inka periods is extremely exceptional (Figure 9). Actually, the density of such pottery styles in sector A is equivalent to that of sector B (Figure 9), which points towards just occasional activity in the site during that time period. 


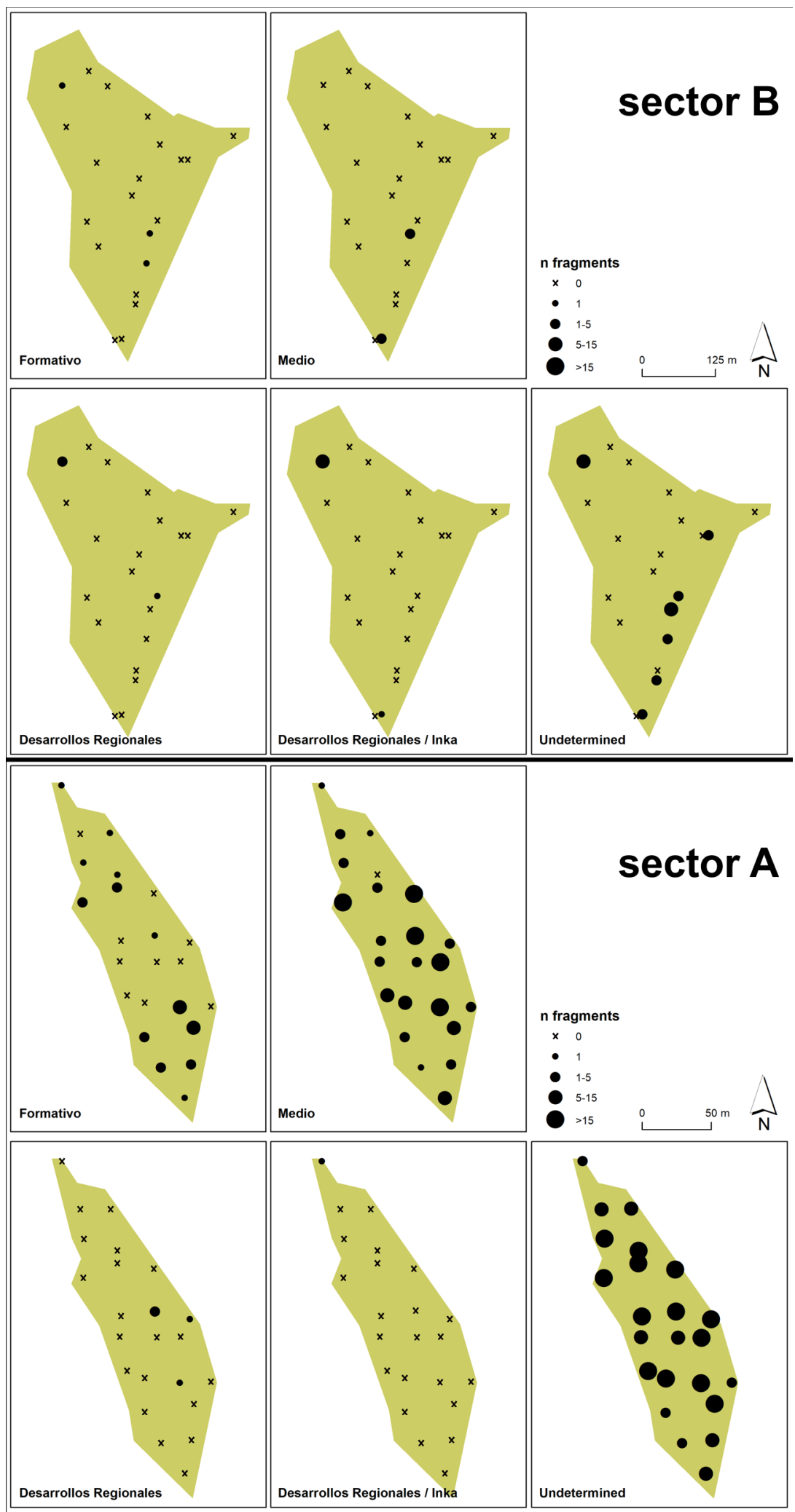

Figure 9. Distribution of pottery per period in Villavil 1, sectors A (bottom) and B (top) (see Figure 8 for a spatial reference) 
With regard to lithic objects and fragments, they are relatively abundant in both sectors (Figure 10, left). The vast majority of them correspond to debitage and cores, with only a few recognizable artifacts. Among these, the presence of fragments of grinding handstones is especially relevant, since they point towards the development of domestic activities. They have only been documented in sector A (Figure 10, right), which again reinforces the idea that this was the only sector with a regular domestic activity. Besides that, lithic production seems mostly expeditive, with little time investment and care, which can be easily related with the abundance of raw material in the vicinity, as some previous studies in the site have shown (Lynch and Lynch, 2016).

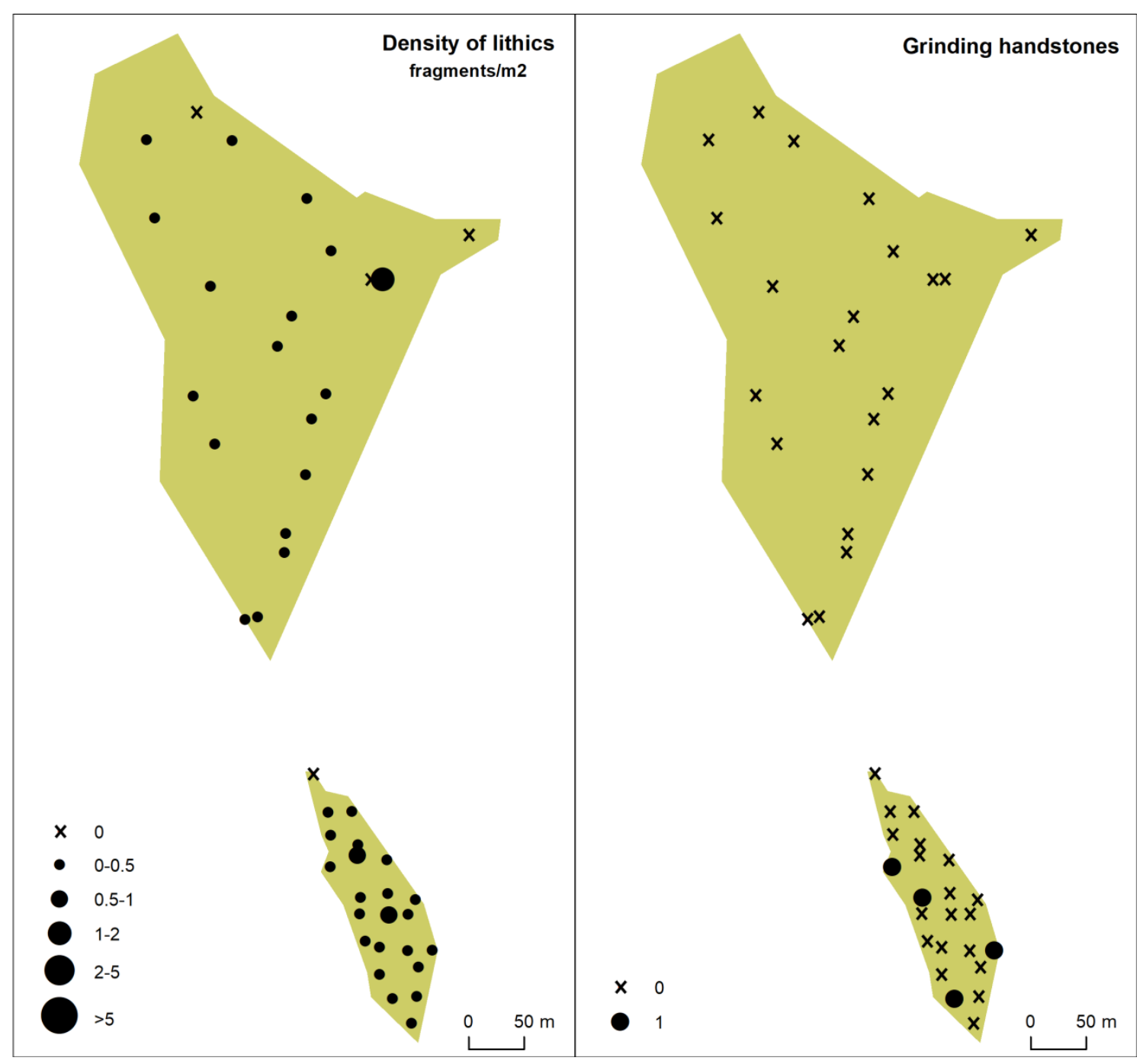

Figure 10. Density of lithic remains and fragments of grinding handstones in Villavil 1 


\subsection{Villavil 2}

The results of the survey in Villavil 2 show a rather different picture. A similar density of pottery and lithic elements was documented across the whole site, except in the rock art promontory and narrow passage (1 and 2 in Figure 7). However, the total number of pottery and lithic fragments collected is significantly lower than in Villavil 1, which suggests that, as was initially hypothesized, Villavil 2 was not a place of regular, intense domestic activity but of occasional use.

A large percentage of the pottery is again of undetermined typology / chronology, but here the vast majority of the styles that can be classified correspond with the later periods of Desarrollos Regionales and Inka (Figure 11). Actually, there is virtually no recognizable pottery from any earlier period, other than a few scattered fragments from the Pretardío. As opposed to Villavil 1, in this case it seems quite clear that the period of use of the site corresponds with the Desarrollos Regionales / Inka, something that shows a good coincidence with the main styles that can be recognized in the rock art panels.

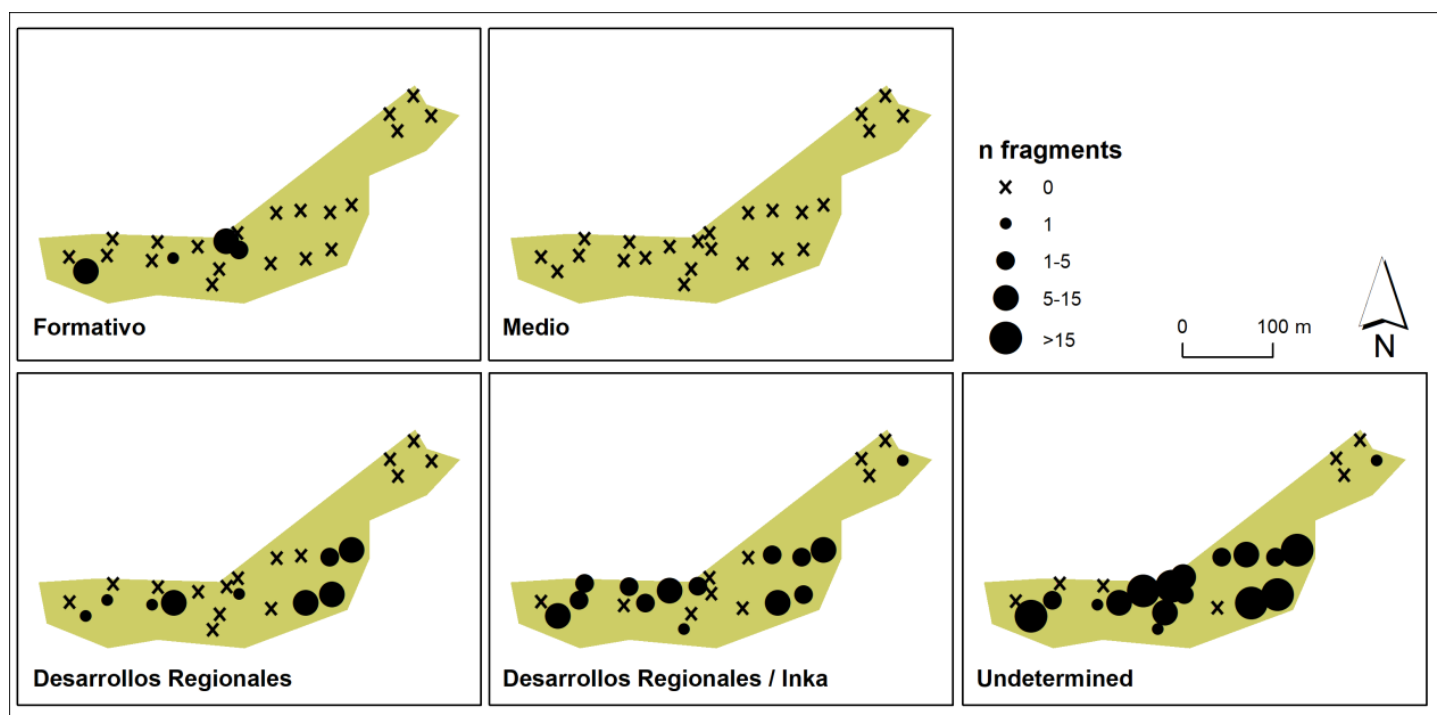

Figure 11. Distribution of pottery per period in Villavil 2 (see Figure 8 for a spatial reference of the limits of the surveyed area)

Regarding lithic remains, the pattern is both spatially homogeneous and very similar to Villavil 1 in terms of the predominant type of remains: debitage and cores. The main difference is the existence of at least three large outcrops with multiple bedrock mortars on the upper side (up to 52 in one case; location in Figure 7). 
Besides the purely archaeological remains (objects, constructions), the most remarkable characteristic of Villavil 2 is the impressive topographic setting, where large outcrops play an essential role. Within an extremely rocky area, some outcrops are especially remarkable for being located in flatter areas, surrounded by open sandy patches. This happens especially along the pathway that goes across the dead-end gorge (Figure 7). It is also on both sides of this pathway that most archaeological remains are found, and they tend to be located next to these isolated outcrops. Besides that, as we have already pointed out, some outcrops located at the access point of the site were selected for the production of rock art, and others were used as bedrock milling stones.

\section{Conclusions}

Our purpose with the work described in this paper was to argue that the application of some simple and affordable tools and methods can bring some benefits for current archaeological practice in a context, Latin American archaeology, where their use is still less frequent than in other parts of the world. As we have shown, the good balance between effort invested and final results is among the most obvious benefits of this approach: with little time and resources, we have produced an accurate and detailed documentation of two archaeological sites that posed some challenges for using the approaches that have been traditional in this area. In addition to that, the documentation we have produced is of multiple granularity, with a degree of detail adapted to the different elements involved, from the site as a portion of the landscape to the rock art motifs in extremely high detail.

Such documentation is not simply a description of the sites and their settings, but also a characterization of their qualities, in terms of chronology and function. The combination of remote sensing tools and field survey has allowed a refinement in the characterization of both sites that, in some cases, conflicts with what was previously assumed. In effect, contrary to what was assumed after the first field approaches years ago, the site of Villavil 1 corresponds with a domestic settlement that was occupied mainly during the Early/Middle Period (ca. 100-1000 $\mathrm{AD})$ and its use in the Desarrollos Regionales and Inka times was seemingly marginal. Although a detailed discussion of the archaeological implications of that is beyond the scope of this paper, it is worth noting that this poses some interesting research questions, particularly 
one: why this site, located on an advantageous position in the landscape, on top of a prominent but accessible plateau, surrounded by good agricultural soils and with easy access to water and raw materials, is abandoned during the late pre-Inka period, to become a place of occasional human activity? Where did the settlers move / were displaced? Although only future work in the site will provide new evidence to answer these questions, it is thanks to the new data collected that we can now pose that question and also provide some evidence to help answering it.

In its turn, the documentation of Villavil 2 confirms its exceptional interest. Mainly in use during the late pre-Inka and Inka periods, the extremely tenuous character of the architecture, the lower density of surface materials, the presence of rock art and, especially, the scenic and dramatic location suggest that this was not an ordinary settlement. Although still some larger excavation is also needed here, the existing evidence strongly suggests that this was a place of temporal but periodical use, which better fits with what we would call a ceremonial space. As has been repeatedly said, in the Andes our divisions between the economic, the social and the symbolic simply doesn't work, since all practices are embedded within a network of strong symbolic meanings (Bray, 2015). But in some particular places those symbolic components would be deeper, or more evident, and the existence of explicit depictions of images through rock art is a key element in highlighting those components (Troncoso, 2018). Villavil 2 represents an excellent example of a place with some special values where prominent natural elements are signified by tenuous but persistent human actions. With its combination of remarkable location, natural features and pre-Inka and Inka rock art designs, it becomes an excellent place to explore how art was used as an active agent in the social process of spatial occupation and dominion imposed by the Tawantinsuyu, as has been argued for other areas (Aschero, 2000; Podestá et al., 2013; Troncoso, 2004, 2018).

Finally, there is still an additional dimension of the work presented here: as was shown, some of the archaeological elements in these sites are extremely fragile and its future preservation is challenging, and perhaps even unlikely. This applies especially to the rock art, which was engraved on boulders that have been affected by aggressive processes of weathering, erosion and sliding. The extremely detailed documentation we have produced constitutes a form of guaranteeing the endurance of these elements through their virtual replicas. Without denying the subtleties and complexities of the relationship between objects and their virtual representations (Garstki, 2017), in this case virtual modelling might be the only way to access these elements in the future, since the agents of degradation are very hard to face, especially in sites like these, of non-monumental nature and relative heritage primacy. The dataset presented here demonstrates 
just a sample of potential applications that can be used to conduct further archaeological, conservation, and outreach studies in ways as yet unexplored for similar inconspicuous archaeological sites.

\section{Acknowledgements}

Milagros Ríos Malán and Emiliano Bentivenga did an excellent work in the field supporting both the mapping and the survey tasks, as well as the identification of archaeological remains at the laboratory. Marco Antonio Giovannetti and Edgardo Ferraris took part in the first stages of the fieldwork and provided useful feedback.

This work was supported by the Consejo Nacional de Ciencia y Tecnología of Argentina (CONICET) under Grant Nº 11220170100033.

\section{References}

Aschero, C.A., 2000. t humanas, camélidos y espacios en la interacción circumpuneña, in: Podestá, M., Hoyos, M.d. (Eds.), Arte en las rocas. Arte rupestre, menhires y piedras de colores en Argentina. Sociedad Argentina de Antropología, Buenos Aires, pp. 15-44.

Balesta, B., Zagorodny, N., Wynveldt, F., 2011. La configuración del paisaje Belén (valle de Hualfin, Catamarca). Revista Relaciones de la SAA XXXVI, 149-175.

Banning, E.B., 2002. Archaeological Survey. Springer, New York.

Bray, T., 2015. The Archaeology of Wak'as. Explorations of the Sacred in the Pre-Columbian Andes. University Press of Colorado, Boulder, Colorado.

Campana, S., 2017. Drones in Archaeology. State-of-the-art and Future Perspectives. Archaeological Prospection 24, 275-296. https://doi.org/10.1002/arp.1569

De Reu, J., De Smedt, P., Herremans, D., Van Meirvenne, M., Laloo, P., De Clercq, W., 2014. On introducing an image-based 3D reconstruction method in archaeological excavation practice. Journal of Archaeological Science 41, 251-262. http://dx.doi.org/10.1016/j.jas.2013.08.020 
De Reu, J., Plets, G., Verhoeven, G., De Smedt, P., Bats, M., Cherretté, B., De Maeyer, W., Deconynck, J., Herremans, D., Laloo, P., Van Meirvenne, M., De Clercq, W., 2012. Towards a three-dimensional cost-effective registration of the archaeological heritage. Journal of Archaeological Science 40, 1108-1121. https://doi.org/10.1016/j.jas.2012.08.040

Doneus, M., Verhoeven, G., Fera, M., Briese, C., Kucera, M., Neubauer, W., 2011. From deposit to point cloud - A study of low-cost computer vision approaches for the straightforward documentation of archaeological excavations. Geoinformatics (XXIIIrd International CIPA Symposium) 6, 81-88. https://doi.org/10.14311/gi.6.11

Field, S., Waite, M., Wandsnider, L., 2017. The utility of UAVs for archaeological surface survey: A comparative study. Journal of Archaeological Science: Reports 13, 577-582. https://doi.org/10.1016/j.jasrep.2017.05.006

Garstki, K., 2017. Virtual Representation: the Production of 3D Digital Artifacts. J Archaeol Method Theory 24, 726-750. https://10.1007/s10816-016-9285-z

Hanus, K., 2018. Mapping the Inhospitable Landscapes of the Orkney Islands using RPAS. Archaeological Prospection 25, 89-95. https://doi.org/10.1002/arp.1582

Lynch, J., 2013. Construcción y organización del espacio incaico al norte del Valle de Hualfin, Catamarca, Argentina. Archaeopress, Oxford.

Lynch, J., 2014. Sitio Villavil: una aproximación a la dinámica local-estatal al norte del valle de Hualfín, Catamarca. Intersecciones en Antropología 15, 491-496.

Lynch, J., 2015. Representaciones rupestres del sitio Villavil 2 (Valle de Hualfín, Catamarca, Argentina). Revista Chilena de Antropología 32, 57-71. https://doi.org/10.5354/07191472.2016 .42500

Lynch, J., Giovannetti, M.A., Páez, M.C., 2013. Ushnus of the Inca provincial region: An analysis of two ceremonial platforms from Inca sites in Catamarca (Argentina). Journal of Anthropological Archaeology 32, 97-108. http://dx.doi.org/10.1016/j.jaa.2012.12.001

Lynch, J., Lynch, V., 2016. Análisis de la tecnología lítica del sitio Villavil localizado en el valle de Hualfín (Provincia de Catamarca, Argentina). Revista Española de Antropología Americana 46, 265-282. http://dx.doi.org/10.5209/REAA.58297

Lynch, V., Lynch, J., 2018. The Study of Rock Art Engravings Through Lithic Technologies: The Villavil 2 Site (Hualfin Valley, Catamarca, Argentina). Lithic Techonology 43, 71-83. https://doi.org/10.1080/01977261.2018.1437978 
Opitz, R., Limp, F., 2015. Recent Developments in HDSM for Archaeology: Implications for Practice and Theory. Annual Review of Anthropology 44. https://oi.org/10.1146/annurevanthro-102214-013845

Opitz, R.S., Cowley, D.C., 2013. Interpreting Archaeological Topography: Lasers, 3D Data, Observation, Visualisation and Applications. Oxbow, Oxford.

Parcero-Oubiña, C., Fábrega-Álvarez, P., Salazar, D., Troncoso, A., Hayashida, F., Pino, M., Borie, C., Echenique, E., 2017. Ground to air and back again: Archaeological prospection to characterize prehispanic agricultural practices in the high-altitude Atacama (Chile). Quaternary International 435, Part B, 95-110. http://dx.doi.org/10.1016/j.quaint.2015.12.050

Parcero-Oubiña, C., Fábrega-Álvarez, P., Troncoso, A., Salazar, D., Hayashida, F., GüimilFariña, A., Mañana-Borrazás, P., Pino, M., Borie, C., 2016. Introduciendo orden en el registro mediante tecnologías no destructivas: experiencias en el estudio de paisajes agrarios prehispánicos en la región de Atacama (Norte de Chile), in: Mayoral Herrera, V. (Ed.), La revalorización de zonas arqueológicas mediante el empleo de técnicas no destructivas. CSIC, Madrid, pp. 223-243.

Podestá, M., Rolandi, D., Santoni, M., Re, A., Falchi, M.P., Torres, M., Romero, G., 2013. Poder y prestigio en los Andes centro-sur. Una visión a través de pinturas escutiformes en Guachipas (Noroeste Argentino). Boletín del Museo Chileno Arte Precolombino 18, 63-88. http://dx.doi.org/10.4067/S0718-68942013000200006

Remondino, F., 2011. Heritage recording and 3D modeling with photogrammetry and 3D scanning. Remote Sensing 3, 1104-1138. https://doi.org/10.3390/rs3061104

Seggiaro, R., Caffe, P.J., Becchio, R., Galli, C., Arnosio, M., Da Poián, G., 2014. Evolución tectónica andina entre las sierras de Hualfín, Capillitas y extremo sur de Aconquija, Catamarca. Revista Asociación Geológica Argentina 71, 500-512.

Thomas, H., 2018. Some like it hot: The impact of next generation FLIR Systems thermal cameras on archaeological thermography. Archaeological Prospection 25, 81-87. https://doi.org/10.1002/arp.1588

Troncoso, A., 2004. El arte de la dominación: arte rupestre y paisaje durante el período incaico en la cuenca superior del río Aconcagüa. Chungará 36, 453-461. http://dx.doi.org/10.4067/S0717-73562004000200016 
Troncoso, A., 2018. Inca Landscapes of Domination: rock art and community in north-central Chile, in: Alconini, S., Covey, A. (Eds.), The Oxford Handbook of the Incas. Oxford University Press, Oxford.

Verhoeven, G., 2011. Taking ComputerVision Aloft - Archaeological Three-dimensional Reconstructions from Aerial Photographs with PhotoScan. Archaeological Prospection 18, 6773. https://doi.org/10.1002/arp.399

Verhoeven, G., Taelman, D., Vermeulen, F., 2012. Computer Vision-Based Orthophoto Mapping Of Complex Archaeological Sites: The Ancient Quarry Of Pitaranha (PortugalSpain). Archaeometry 54, 1114-1129. https://doi.org/10.1111/j.1475-4754.2012.00667.x

Wernke, S.A., Kohut, L.E., Traslaviña, A., 2017. A GIS of affordances: Movement and visibility at a planned colonial town in highland Peru. Journal of Archaeological Science 84, 2239. https://doi.org/10.1016/j.jas.2017.06.004

Wynveldt, F., Balesta, B., Iucci, M.E., 2013. El paisaje tardío del Valle de Hualfín: una reconstrucción arqueológica desde los poblados protegidos. Comechingonia 17, 191-215. https://doi.org/10.37603/2250.7728.v17.n2.18197 